\title{
天然水中有機物の光分解装置の製作と 化学発光法を用いたその性能評価
}

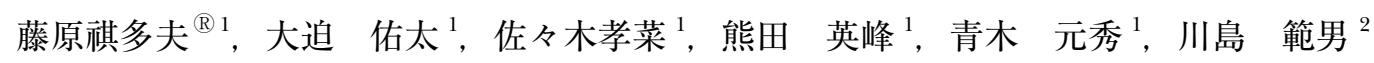

化学的酸素要求量 (COD) 測定法は, 様々あるが, 日本国内で最も用いられているのは, 法定試験方法で ある酸化剤を過マンガン酸カリウムとした $\mathrm{COD}_{\mathrm{Mn}}\left(100^{\circ} \mathrm{C}\right.$ に扔ける過マンガン酸カリウムによる酸素要求 量) である. 本研究では, $\mathrm{COD}_{\mathrm{Mn}}$ に則り，ルミノール化学発光を利用して全フロー系で測定する方法を考案 し，その評価を行った．ここでは，有機物と反応した後の残存した $\mathrm{MnO}_{4}{ }^{-}$を，直接ルミノール化学発光で定 量, $\mathrm{COD}$ 対応值とする. また天然水の $\mathrm{COD}_{\mathrm{Mn}}$ を低下 (分解) するための光分解装置の作製とその分解能評 価を化学発光で行う方法を考案した．ここでは, PFA マイクロチューブ（内径 $0.2 \mathrm{~mm}$, 外径 $0.4 \mathrm{~mm}$ ）を石 英ランプに巻きつけ, 低圧水銀ランプを石英管中心部から照射する, 安価かつ簡便な光分解装置を作製した. 低圧水銀ランプの $254 \mathrm{~nm}$ 輝線の透過率は, 石英管 : $82.8 \%$, PFA マイクロチューブ : $55.0 \%$ であった. 従っ て, 低圧水銀ランプから照射されている $254 \mathrm{~nm}$ 輝線はPFA マイクロチューブを通っている試料に $45.5 \%$ 当 たっていることになる。この装置を用いて, 有機化合物水溶液及び天然水の COD 測定と, その光分解に適 用した．ここで COD についてほとんど光分解できない天然水から， $90 \%$ まで分解できるものが存在した.

\section{1 緒言}

現在の水質污染の 7 割近くは一般家庭からの生活排水に 含まれる有機化合物が污染源となっている。このような有 機化合物を分解するにあたり，自然のエネルギーを使った クリーンな分解方法が注目を浴びている。 その手法には微 生物や植物を使った方法もあるが, 微生物は分解反応の過 程で悪臭が発生し, 生成された残骸物の処理等に対策が必 要であり, 植物では植物の生育に必要な土地の確保や植物 の生育条件等の問題がある，その中で，分解後に有害物質 を出さない光分解は対象物に直接作用するため, 即効性が あり，扱いが簡便であるといった利点がある．特に $\mathrm{TiO}_{2}$ を 光触媒とする方法は, 多数の研究が発表されている ${ }^{1) \sim 4)}$. 今日の研究の主流は, 様々な光分解触媒を使った方法が主 流となっており, そこでは, 光源としてキセノンランプや 数ワット以上の水銀ランプが用いられているほか, 可視光 の活用も報告されている ${ }^{6) \sim 9)}$. また光触媒の担持法, 触媒 の成型法等が検討されている ${ }^{10) \sim 13)}$. 本研究では, 光照射に 長流路，毛細管を使う方法を検討した，すなわち $100 \mathrm{~m}$ 長 の PFA（テトラフルオロエチレン・パーフルオロアルキル ビニルエーテル共重合体) マイクロチューブ及び低圧水銀 ランプを用いて, 安価かつ簡便な光分解装置を作製し，こ

\footnotetext{
${ }^{1}$ 東京薬科大学生命科学部：192-0392 東京都八王子市堀之内 1932-1

${ }^{2}$ 日本工業用水協会 : 162-0823 東京都新宿区神楽河岸 1-1
}

の分解効率を評価した。

代表的な天然水（湖沼・河川水）の有機化合物による水 質污染の指標として, 化学的酸素要求量 $(\mathrm{COD} ;$ chemical oxygen demand）が用いられている. COD 測定法は, 様々 あるが，日本国内で最も用いられているのは，法定試験方 法である酸化剂を過マンガン酸カリウムとした $\mathrm{COD}_{\mathrm{Mn}}$ ( $100^{\circ} \mathrm{C}$ における過マンガン酸カリウムによる酸素要求量 $)$ である. 本研究では, $\mathrm{COD}_{\mathrm{Mn}}$ を基盤として,ルミノール化 学発光を利用して測定する方法を考案した. $\mathrm{COD}_{\mathrm{Mn}}$ 測定法 は, 酸性条件下で $\mathrm{MnO}_{4}{ }^{-}+8 \mathrm{H}^{+}+5 \mathrm{e} \leftrightarrows \mathrm{Mn}^{2+}+4 \mathrm{H}_{2} \mathrm{O}$ の 反応に基づいている. そこで有機物と反応した後の残存し た $\mathrm{MnO}_{4}{ }^{-}$を, ルミノール化学発光で定量するフロー法を 検討した（ここでは, 化学発光強度が大きい試料は, 残存 している $\mathrm{MnO}_{4}{ }^{-}$が多いので, 試料中の有機物は少なく, $\mathrm{COD}_{\mathrm{Mn}}$ 対応值は低いということになる。逆に, 化学発光強 度が小さい試料は, 残存している $\mathrm{MnO}_{4}{ }^{-}$が少ないので, 試 料中の有機物は多く, $\mathrm{COD}_{\mathrm{Mn}}$ 対応值は高いということにな る). 本研究では, 前記の光分解装置通過前後の COD を測 定するために，全フローシステムを製作した．ここでは試 水を光分解装置に連続的に流しながら，その一部を 6 方バ ルブを用いて採取し，ルミノール化学発光によって $\mathrm{MnO}_{4}{ }^{-}$を測定するシステムとした. 


\section{2 実験}

\section{$2 \cdot 1$ 試薬及び試料}

本研究で用いた試薬のうち, 特別な調製方法で調製した ものを以下に示す.

\section{$\mathbf{2} \cdot \mathbf{1} \cdot \mathbf{1}$}

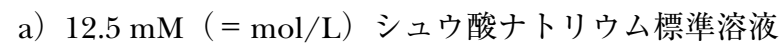
シュウ酸ナトリウム $\left(\mathrm{Na}_{2} \mathrm{C}_{2} \mathrm{O}_{4}\right)$ を $200^{\circ} \mathrm{C}$ で 1 時間乾燥 し, デシケーター中で放冷した後, その $1.68 \mathrm{~g}$ を量りとる. これを MilliQ 水に溶かし， メスフラスコを用いて $1.0 \mathrm{~L} と$ した.

b） $12.5 \mathrm{mM}$ シュウ酸ナトリウム溶液

JIS K 8528 に規定するシュウ酸ナトリウム $\left(\mathrm{Na}_{2} \mathrm{C}_{2} \mathrm{O}_{4}\right)$ $1.8 \mathrm{~g}$ を水に溶かして $1 \mathrm{~L}$ とした.

$\mathbf{2 \cdot 1 \cdot 2} 5 \mathrm{mM}$ 過マンガン酸カリウム溶液 過マンガ ン酸カリウム $\left(\mathrm{KMnO}_{4}\right) 0.8 \mathrm{~g}$ を MilliQ 水 $1050 \sim 1100 \mathrm{~mL}$ に溶かし，これを $1 〜 2$ 時間静かに煮沸した後，一夜放置 後, ガラス沪過器 (G-4) で沪過し, 褐色瓶に保存した.

この溶液はおおよそ $5 \mathrm{mM}$ になっているが, 次のように して標定した. MilliQ水 $100 \mathrm{~mL}$ を $300 \mathrm{~mL}$ の三角フラス コにとり, $\mathrm{H}_{2} \mathrm{SO}_{4}(1+2) 10 \mathrm{~mL}$ を加え, ついでホールピ ペットで $12.5 \mathrm{mM} \mathrm{Na}_{2} \mathrm{C}_{2} \mathrm{O}_{4}$ 標準溶液 $10 \mathrm{~mL}$ を加えて 60 〜 $80^{\circ} \mathrm{C}$ に保ちながら, $5 \mathrm{mM} \mathrm{KMnO}_{4}$ 溶液で滴定し, 溶液が 無色からわずかに淡紅色になった点を終点とした。滴定に $a \mathrm{~mL}$ を要したとすれば, そのファクター $f$ は次の式で求め た。

$$
f=10 / a
$$

2・1・3 ルミノール化学発光試薬 ルミノール化学発 光による過マンガン酸イオンの測定として, 水酸化ナトリ ウム (試薬特級, 和光純薬工業, 大阪), ルミノール (生化 学用, 和光純薬工業, 大阪), 1,10-フェナントロリン一水 和物 (試薬特級, 和光純薬工業, 大阪), $25 \%$ アンモニア 水 (精密分析用, 和光純薬工業, 大阪), 硫酸アンモニウム (試薬特級, 関東化学, 東京) を使用した.ルミノールは, $0.1 \mathrm{M}$ 水酸化ナトリウム水溶液に溶かした後, 硫酸アンモ ニウム緩衝液（25\% アンモニア水で $\mathrm{pH} 9.6$ に調整）に溶 解した。すなわち $3 \mathrm{mM}$ ルミノール溶液 $50 \mathrm{~mL}$ と $0.01 \mathrm{M}$ 1,10-フェナントロリン一水和物 $50 \mathrm{~mL}, 75 \mathrm{mM}$ 硫酸アンモ ニウム緩衝液 $150 \mathrm{~mL}$ を混合, これを化学発光液として用 いた。

\section{$2 \cdot 2$ COD 測定試料}

光分解装置の性能を評価するため, タニシガ池（東京都 八王子市：表層水を試料瓶に直接採取), 大栗川 (東京都 八王子市：表層水を試料瓶に直接採取), 浅川 (東京都八
王子市：表層水を試料瓶に直接採取), $50.0 \mu \mathrm{M} \mathrm{D}(+)$-グル コース水溶液, $10.0 \mu \mathrm{M}$ フタル酸水素カリウム水溶液, 10.0 $\mu \mathrm{M}$ 2-ナフチルアミン-1-スルホン酸水溶液を用いた.

また，光分解-COD 測定システムの検証用には，東京薬 科大学排水処理センターの生活排水 $(09 / 9 / 11$ 採水, $\left.\mathrm{COD}_{\mathrm{Mn}}: 107 \mathrm{mg} / \mathrm{L}\right)$ 及び実験排水 $\left(09 / 9 / 11\right.$ 採水, $\mathrm{COD}_{\mathrm{Mn}}$ : $26 \mathrm{mg} / \mathrm{L}), 50 \mu \mathrm{M}$ グルコース水溶液, $10 \mu \mathrm{M}$ 2-ナフチルア ミン-1-スルホン酸水溶液を用いた。 なお有機化合物は, す ベて MilliQ水で希釈したものである.

\section{$2 \cdot 3$ 測定方法}

\section{$2 \cdot 3 \cdot 1$ COD 測定法 $\left(\mathrm{COD}_{\mathrm{Mn}}\right)$}

(1) 試料水 $50 \mathrm{~mL}$ を $300 \mathrm{~mL}$ の三角フラスコにとり, MilliQ 水を加えて約 $100 \mathrm{~mL}$ とし, 振り混ぜながら $\mathrm{H}_{2} \mathrm{SO}_{4}$ (1+2) $10 \mathrm{~mL}$ を加えた.

(2) $5 \mathrm{mM} \mathrm{KMnO}_{4}$ 溶液 $10 \mathrm{~mL}$ を，ビュレットを用いて加 え, 直ちに沸騰水水浴中に入れ, 30 分間加熱した.

(3) 水浴から出して, $12.5 \mathrm{mM} \mathrm{Na}_{2} \mathrm{C}_{2} \mathrm{O}_{4}$ 溶液 $10 \mathrm{~mL}$ をホー ルピペットで加え, よく振り混ぜた.

(4) $5 \mathrm{mM} \mathrm{KMnO}_{4}$ 溶液で滴定し, 溶液が無色からわずか に淡紅色になった点を終点とした.

(5) 試料水の代わりに MilliQ水 $100 \mathrm{~mL}$ を用い, 上記と同 様に操作して, 空試験における逆滴定值を求める.

試料水 $V \mathrm{~mL}$ を用いた場合に滴定に要した $5 \mathrm{mM} \mathrm{KMnO}_{4}$ 溶液の量を $b \mathrm{~mL}$, 空試験のそれを $c \mathrm{~mL}$ とし, 次式によっ て CODを算出した.

$$
\operatorname{COD}\left(\mathrm{O}_{2} \mathrm{mg} / \mathrm{L}\right)=f \times 0.2 \times(b-c) \times 1000 / V
$$$$
0.2: 5 \mathrm{mM} \mathrm{KMnO}_{4} \text { 溶液 } 1 \mathrm{~mL} \text { の酸素相当量 }(\mathrm{mg})
$$

2・3・2 ルミノール化学発光評価前項で述べたルミ ノール化学発光緩衝液を HPLC ポンプ（日本分光, model PU2080）で流速 $4.0 \mathrm{~mL} / \mathrm{min}$ で流し, $\mathrm{KMnO}_{4}(0 \sim 500$ $\mu \mathrm{M})$ を打ち込み（PEEK製インジェクター, Rheodyne, model9055-022 ; サンプルループ: $20 \mu \mathrm{L})$, 化学発光強度 を測定した（化学発光検出器：日本分光, model K25-CL, インテグレーター：日本分光, model 807-IT).

$2 \cdot 3 \cdot 3$ 光分解-化学発光測定システムの作製 Fig. 1 に, このシステム全体の概念図を示す. 光分解装置には, 光源には, ペン型低圧水銀ランプ〔L937-02, 浜松ホトニク ス, 静岡; 主な輝線スペクトル : $254 \mathrm{~nm}$; 放射出力強度 : $5 \mu \mathrm{W} / \mathrm{cm}^{2}$ (1 $\mathrm{m}$ 隔てた点において)] 2 本を, 反対向きに して, 石英菅 $($ 外径 $=30 \mathrm{~mm}$, 内径 $=29 \mathrm{~mm}$, 長さ $=120$ $\mathrm{mm}$ ）内に挿入した. この石英管外径に PFA マイクロ チューブ $($ 内径 $=0.2 \mathrm{~mm}$, 外径 $=0.4 \mathrm{~mm}$, 長さ $=100 \mathrm{~m}$ ) を巻きつけた.

硫酸酸性 $\mathrm{KMnO}_{4}\left(100 \mu \mathrm{M} \mathrm{KMnO}_{4}, 6 \% \mathrm{H}_{2} \mathrm{SO}_{4}\right)$ の送液 


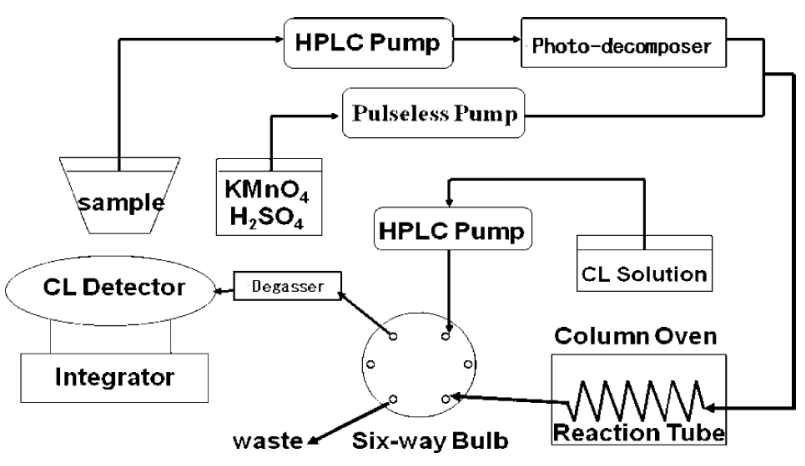

Fig. 1 Conceptual figure for the system of the photodecomposition and chemiluminescence detection of COD

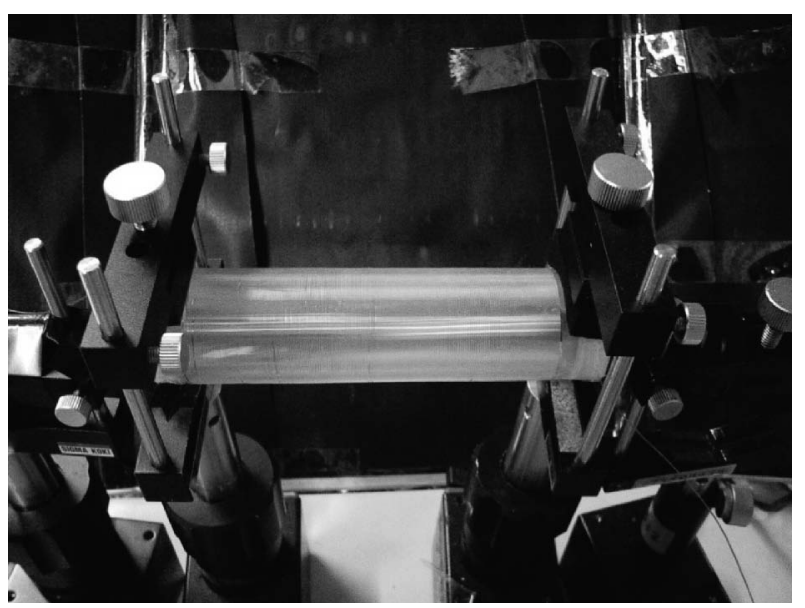

Fig. 2 Photograph of the photo-decomposer (photodecomposition system)

In the figure, the quartz tube wound with a PFA microtube was supported by a lens holder (model LHA-60 purchased from Sigma-koki : width (length of upper and lower black arms) $=86 \mathrm{~mm}$.

には無脈流ポンプ（サヌキ工業，DMX-2000）を用い，更 に光分解装置を通じた前後の試料中の COD 変化を，フ ロー系で測定するシステムを製作した。試料と硫酸酸性 $\mathrm{KMnO}_{4}$ はジョイントで混合させた後, 流速は $0.1 \mathrm{~mL} / \mathrm{min}$ で, カラムオーブン（日本分光, model CO-960）に導入し た. オーブン内では, 反応チューブ（テフロン ${ }^{\circledR}$ 製, i.d. = $1.0 \mathrm{~mm}$, o.d. $=1 / 16 \mathrm{in}, 1=10 \mathrm{~m}$ : 本研究の流速では, 約 30 分溶液は内部を流れる）を入れて反応液を加温した後, 六方バルブ (PEEK 製, Rheodyne, type 9060) のサンプル チューブ $(20 \mu \mathrm{L})$ へ流れる. その後, 流路を切り替え化学 発光用緩衝溶液と併せたのち，デガッサー（WORL Lab, model LG-02）を通して, 化学発光検出器に導入した. 従っ て試料の流れは, 光分解装置を通った後, $\mathrm{KMnO}_{4}(6 \%$ $\left.\mathrm{H}_{2} \mathrm{SO}_{4}\right)$ と混ざり, カラムオーブン $\left(80^{\circ} \mathrm{C}\right)$ 内の反応チュー ブで加温され, 六方バルブのサンプルチューブ $(20 \mu \mathrm{L})$ に

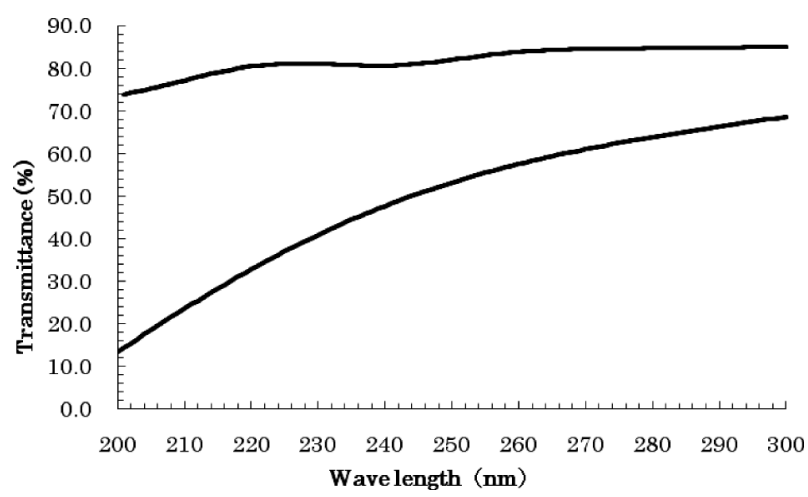

Fig. 3 Transmittance of the quartz tube (upper line) and PFE sheet (lower line) used in the photo-decomposition system for COD

Transmittance of the PFE (sheet) has the same thickness $(0.2 \mathrm{~mm})$ as the PFE tube employed in the photodecomposition system.

流れる. 同時に, 化学発光液も六方バルブに流れ, バルブ 切り替え時に, 試料 $+\mathrm{KMnO}_{4} / \mathrm{H}_{2} \mathrm{SO}_{4}$ 混合/液と合流し, 化学発光が生じこれを測定する.

なお本研究に示したデー夕は，5回以上の実測（測定回 数）の平均值である.

\section{3 結果と考察}

\section{$3 \cdot 1$ 光分解装置の評価}

$3 \cdot 1 \cdot 1$ 光分解装置の素材の光透過性 分解装置の写 真を Fig. 2 に示す. 光分解装置を構成している石英管と PFA マイクロチューブについて, 低圧水銀ランプの輝線に 対応する, 紫外領域の透過率スペクトルを, 紫外・可視分 光光度計（V-550, 日本分光，東京）で測定した。 その結果 を Fig. 3 に示す. Fig. 3 より, 低圧水銀ランプの $254 \mathrm{~nm}$ 輝 線の透過率は, 石英管 : $82.8 \%$, PFA マイクロチューブ : $55.0 \%$ であった. 従って, 低圧水銀ランプから照射されて いる $254 \mathrm{~nm}$ 輝線は PFA マイクロチューブを通っている試 料に $45.5 \%$ 当たっていることになる.

$3 \cdot 1 \cdot 2$ 光分解装置の分解効率の測定 分解装置に脱 気した試料を HPLC ポンプ (PU-1580, 日本分光, 東京) を用いて，流出液を貯留して，2·3・1 の方法で COD を測 定した. グルコースの分解と, 光分解装置内流速の関係を Fig. 4 に示す. また様々な試料を流速 $0.8 \mathrm{~mL} / \mathrm{min}$ で光分解 装置を通過させたときの分解結果を Fig. 5 に示す.

紫外線照射時間による $\mathrm{COD}_{\mathrm{Mn}}$ の変化を確認した。光分 解装置への送液速度と装置内の滞留時間を Table 1 に示す. 紫外線照射時間が増大すると, 分解率も上昇することを確 認した. $50 \mu \mathrm{M}$ グルコースにおいては, 7.85 分（流速 $=0.4$ $\mathrm{mL} / \mathrm{min})$ で分解率が定常的になった。このことは，少な くとも PFEマイクロチューブを用いた長さ $100 \mathrm{~m}$ の分解装 


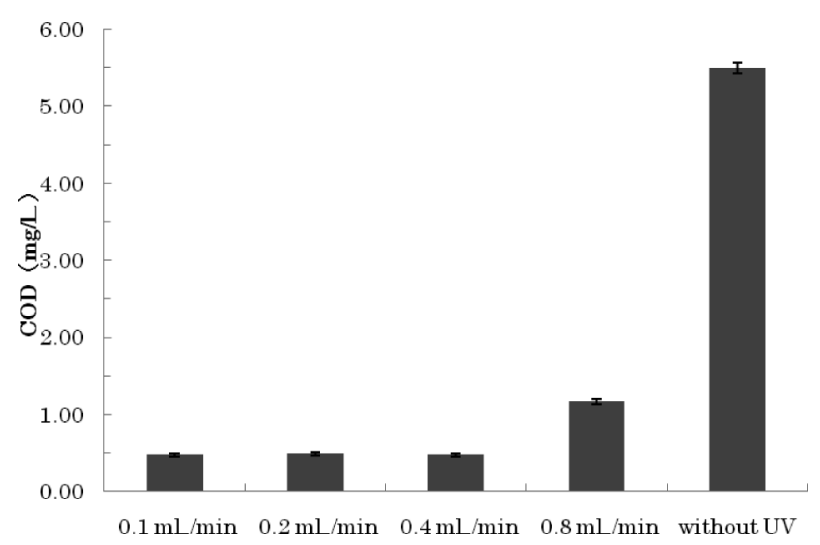

Fig. 4 Dependence of the decomposition rate of 50.0 $\mu \mathrm{M}$ glucose on the flow rate inside the photodecomposition system

置で，十分な分解時間が担保されている（流速 $0.4 \mathrm{~mL} / \mathrm{min}$ 以下）と考えられる. な打 $0.8 \mathrm{~mL} / \mathrm{min}$ 以上の流速増加は, システムの安定性から行うことができなかった。ここで製 作した光分解装置により, 多くの試料において $\mathrm{COD}_{\mathrm{Mn}}$ は 低くなることを確認した〔光分解装置通過後の COD 量の 平均値（通過前を $100 \%$ とする）：タニシが池 $=50 \%$, 大 栗川 $=54 \%$, 浅川 $=100 \%$, グルコース $=21 \%$, フタル酸 水素カリウム $=201 \%, 2$-ナフチルアミン-1-スルホン酸 = $30 \%$ ]. Fig. 6 に示すように, 天然水の分解は, 水銀の発光 線の $254 \mathrm{~nm}$ の吸収強度とほほ対応しており, 浅川のよう に $254 \mathrm{~nm}$ に吸収帯がないために $\mathrm{COD}_{\mathrm{Mn}}$ が変化しなかった 試料も存在した．またフタル酸水素カリウムのように, 紫 外線照射により, $\mathrm{KMnO}_{4}$ の酸化を受けやすい化合物に変 化し，見かけ上 $\mathrm{COD}_{\mathrm{Mn}}$ が 2 倍ほど高くなる例も見られた （LC-MS の結果では，生成物の特定はできなかったが，低 分子量の化合物になっていた)，従ってあらゆる試料につ いて, この光分解装置が $\mathrm{COD}_{\mathrm{Mn}}$ を低下させるわけではな いということを確認した．な打様々な二酸化チタンを分解 試料に添加したが，現在まで分解の増大効果は認められな かった，すなわち、ルチル，アナターゼ，アモルファス型 の粉末 (和光純薬から購入) を $0.1 \sim 1 \%$ 添加, 分散した ものを流してみたが，ほぼ分解効率は無添加時に比較して 低下した。こうした光触媒を使用する場合, フィルムや ファイバー710) 12) 形状で利用したり，また $500 \mathrm{~W}$ 程度の高 輝度ランプ ${ }^{6}$ が用いられて㧍り, 低圧安価なランプを使用 する本方法は, 光触媒を利用しない場合有効であると思わ れる。

\section{$3 \cdot 2$ 化学発光法による過マンガン酸イオンの定量}

過去においてもルミノール化学発光を利用した COD 測 定に関する研究は報告されている(14)15)が, 本研究のよう に $\mathrm{MnO}_{4}^{-}$をルミノール化学発光で検出する研究は報告さ

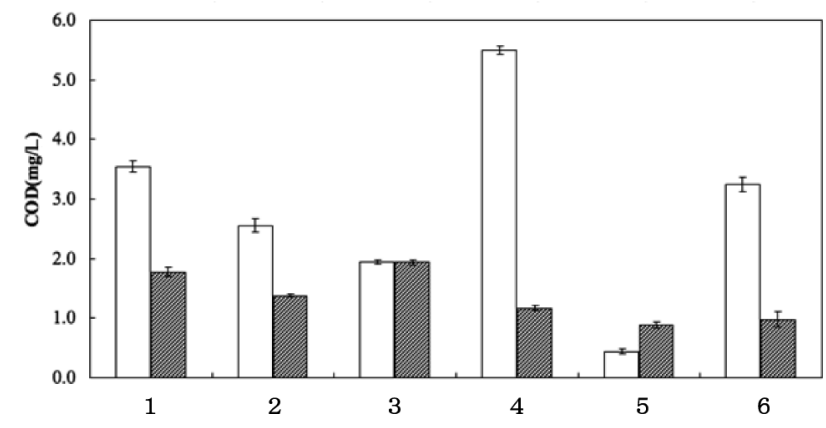

Fig. 5 COD measured before (blank) and after (shadowed) the photodecomposition system

1: Tanishigaike-pond, 2: Okurigawa-river, 3 : Asakawariver, $4: 50 \mu \mathrm{M}$ glucose, $5: 10 \mu \mathrm{M}$ potassium hydrogen phthalate, $6: 10 \mu \mathrm{M}$ 2-naphthylamin-1-sulfonic acid

Table 1 Flow rate and residential time in the Photodecomposer

\begin{tabular}{lrrll}
\hline Flow rate (mL/min) & 0.1 & 0.2 & 0.4 & 0.8 \\
Residential time (min) & 31.4 & 15.7 & 7.85 & 3.93 \\
\hline
\end{tabular}

れていない. ルミノール化学発光は, 弱塩基性下で起こる ので, 化学発光液について検討を行い, $2 \cdot 1 \cdot 3$ で記述した 溶液（ルミノール発光溶液）を用いた。 ここで, 1,10-フェ ナントロリンは, 金属イオンの妨害を防ぐために加えた. すなわち化学発光は銅, コバルトなどの遷移金属イオン及 びその錯体によって触媒され，増大することが知られてい るためである。硫酸アンモニウム緩衝液を混合しないで作 製した化学発光液, 1,10-フェナントロリン一水和物を混合 しないで作製した化学発光液, ルミノールのみで作製した 化学発光液は, いずれも化学発光強度が不安定（再現性あ る化学発光ピークが取得できない) であり, $\mathrm{MnO}_{4}{ }^{-}$量を直 接ルミノール化学発光の強度で測定する本研究には使用で きないことを確認した.

まず, Fig. 7 の系で, 化学発光液を流速 $4.0 \mathrm{~mL} / \mathrm{min}$ で流 し, $\mathrm{KMnO}_{4}(0 \sim 500 \mu \mathrm{M})$ を打ち込み, 化学発光強度を測 定した. Fig. 8 にルミノール濃度と化学発光強度の関係を 示す. $5.0 \mathrm{mM}$ ルミノールを混合したときの化学発光液が, 最大の化学発光強度を示したので, $5.0 \mathrm{mM}$ ルミノールを 化学発光液調製の際に使用することにした. Fig. 9 に緩衝 液濃度と化学発光強度の関係を示す。緩衝液濃度 $2.0 \mathrm{M}$ で 化学発光強度は最大となった. 化学発光強度は, $1.00 \mathrm{M}$ の 方が $2.00 \mathrm{M}$ より 小さかったが, 試薬の使用量及び液性（流 路内流れの安定性) を勘案して, 測定には $1.00 \mathrm{M}$ を使用す ることにした．以上，上記のルミノール化学発光溶液を用 いて，COD を測定することが可能であることが明らかと なった。ここでキャリヤーの流速を上げると, 化学発光強 

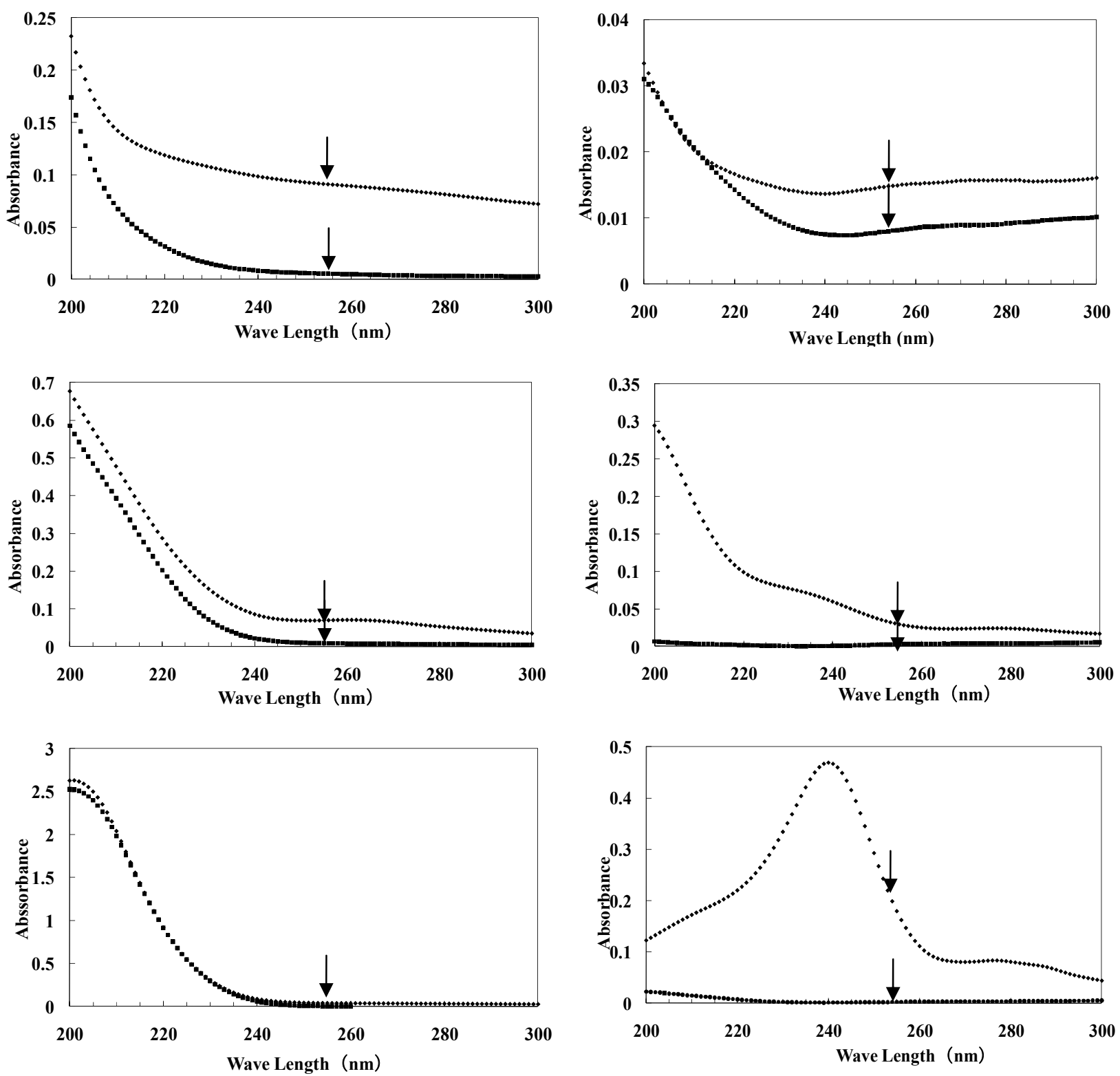

Fig. 6 Absorption spectra of the samples before (upper line) and after (lower line) passing through the photo-decomposer

Arrows show the wavelength at $354 \mathrm{~nm}$. Upper left: Tanishigaike pond, Upper right : glucose, Middle left : Ogurigawa river, Middle right : potassium hydrogen phthalate, Lower left : Asakawa river, Lower right : 2-naphthylamin-1-sulfonic acid

度も上昇したが, 化学発光検出器の耐圧である $10 \mathrm{~kg} / \mathrm{cm}^{2}$ を超えてしまう恐れがあったので, $4.0 \mathrm{~mL} / \mathrm{min} に$ に決定し た.

Fig. 10 に上記の条件下での $\mathrm{KMnO}_{4}$ の濃度と化学発光強 度の相関を示す. $\mathrm{KMnO}_{4}$ 濃度 $0 \sim 500 \mu \mathrm{M}$ の範囲で化学発 光強度は $\mathrm{KMnO}_{4}$ 濃度増加により増加するが, 直線的な比 例関係はなかった. $\mathrm{KMnO}_{4}$ 濃度が $400 \mu \mathrm{M}$ を超えると化学 発光強度にある程度の差がないので, $\mathrm{KMnO}_{4}$ の消費が少 ない試料（COD $\mathrm{CO}_{\mathrm{Mn}}$ が低い試料）を測定するのが困難であ る.しかし Fig. 10b に示したように, $50 \mu \mathrm{M}$ 以下の濃度で は, $\mathrm{KMnO}_{4}$ 濃度と化学発光強度が直線的に比例する. 従っ

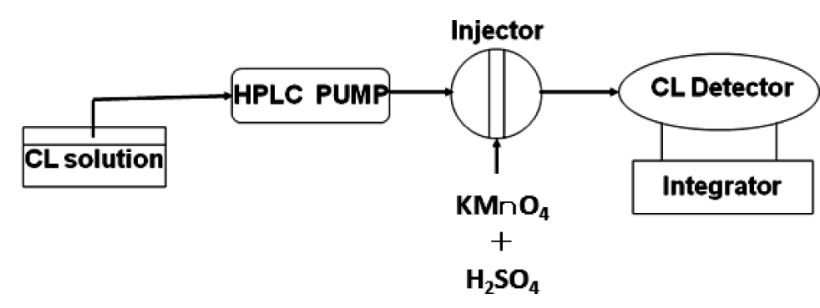

Fig. 7 The system for inspecting the relationship between the intensity of chemiluminescence and the concentration of injected $\mathrm{KMnO}_{4}$ 


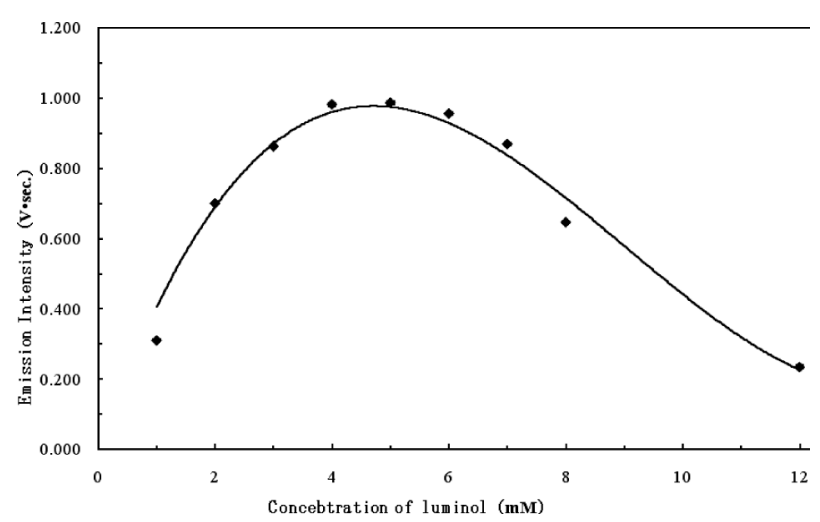

Fig. 8 Concentration of luminal vs chemiluminescence intensity

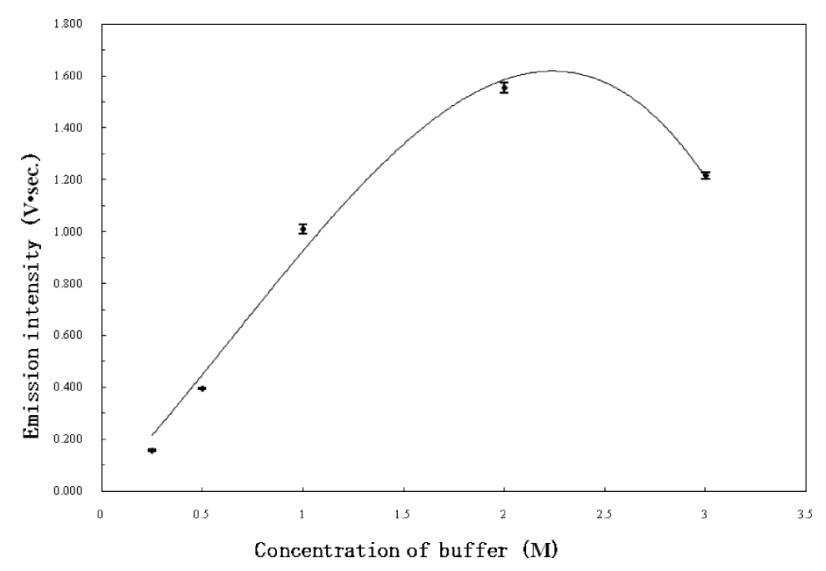

Fig. 9 Chmiliminescence intensity vs. buffer concentration

て， $\mathrm{COD}_{\mathrm{Mn}}$ の測定には, $50 \mu \mathrm{M} \mathrm{KMnO}_{4}$ を使用することに した.

\section{$3 \cdot 3$ 光分解-化学発光測定システムでの測定}

Fig, 11 にFig. 1 のシステムで評価した化学発光強度変化 を示す. 化学発光強度 (MilliQ 水-各試料) は, 各試料と 反応し消費された $\mathrm{KMnO}_{4}$ 量を表している．紫外線照射前 の各試料の $\mathrm{COD}_{\mathrm{Mn}}$ を $100 \%$ とすると, 紫外線を照射した

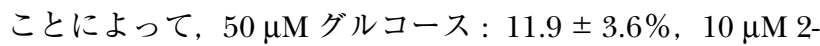
ナフチルアミン-1-スルホン酸 : $20.3 \pm 4.3 \%$, (東京薬科大 学排水処理センター内の) 生活排水: $98.0 \pm 2.0 \%$, 実験排 水：23.7 $\pm 7.9 \%$ になった. ここで得られた分解効率は, 光分解装置を評価するために行った $3 \cdot 1 \cdot 2$ (手動滴定法) の結果に比較して, グルコース及び 2-ナフチルアミン-1スルホン酸では，見掛け上分解効率が向上している．これ はバッチ法に比較して, Fig. 1 の Column Oven 中では反応 の進行が進んでいるのか, あるいは過マンガン酸イオンが 加温用オーブン内で有機物との共存で吸着を起こしている 等の可能性が考えられる.
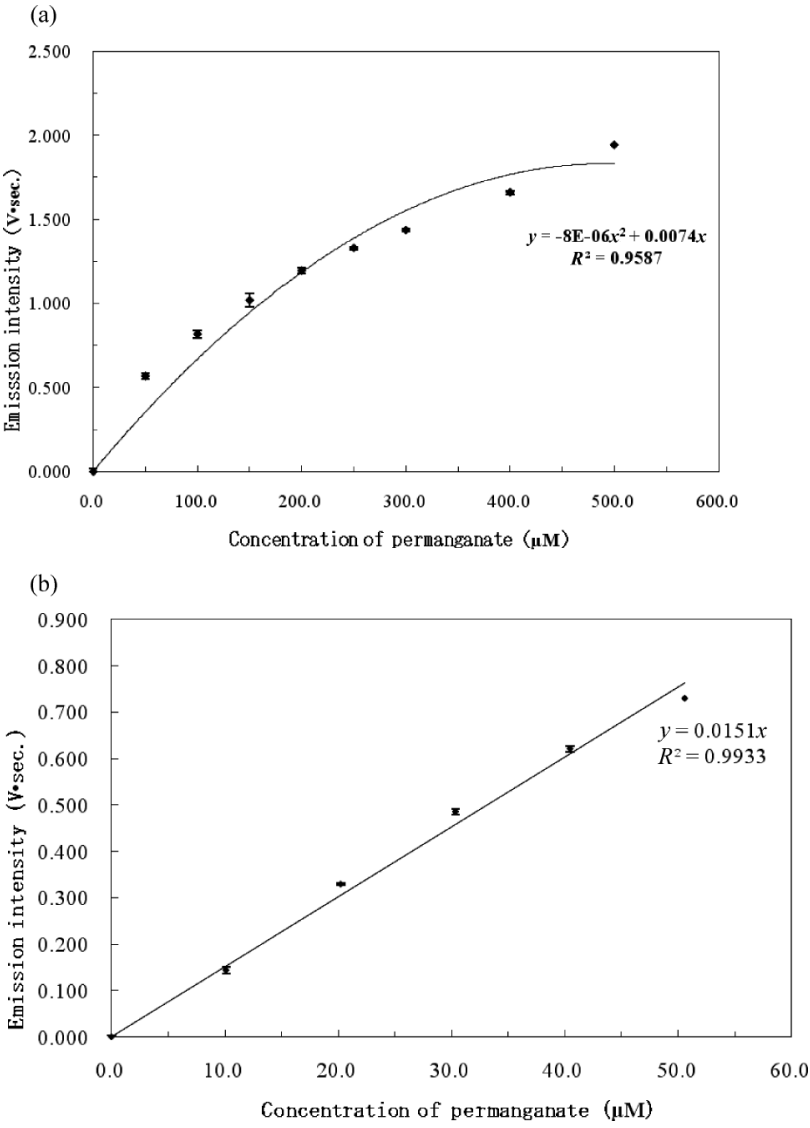

Fig. 10 Concentration of permanganate vs chemiluminescence intensity (integrated value)

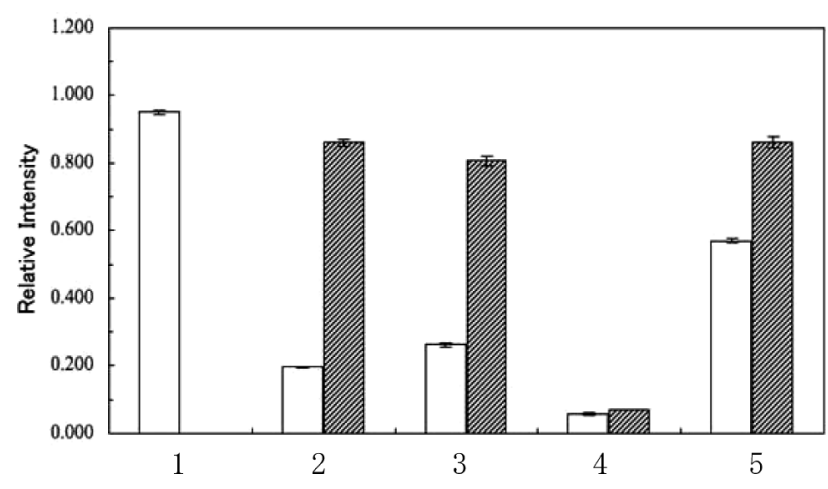

Fig. 11 Chemiluminescence intensity for the samples with (shadowed) and without (blank) the photodecomposituin system when using the system shown in Fig. 1

SAMPLES

1: MilliQ water 2: $50 \mu \mathrm{M}$ glucose, 3: $10 \mu \mathrm{M}$ 2-naphthylamin-1-sulfonic acid, $4:$ municipal waste (Tokyo University of Pharmacy and Life Sciences), 5 : drainage from the experimental area (Tokyo University of Pharmacy and Life Sciences). 
報 文 藤原, 大迫, 佐々木, 熊田, 青木, 川島：天然水中有機物の光分解装置の製作と化学発光法を用いたその性能評価 1027

4 結 言

光分解装置とルミノール化学発光を利用した COD 測定 法を組み合わせ, 光分解一化学発光測定システムを作製し た. ここでは光分解のため, PFA マイクロチューブと低圧 水銀ランプを用いて, 安価かつ簡便な光分解装置を作製し た．構成している石英管と PFA マイクロチューブについ て, 低圧水銀ランプの $254 \mathrm{~nm}$ 輝線の $45.5 \%$ が, 試料液に 当たっていることを確認した。次に，実際に試料を光分解 装置に流し，紫外線照射前後の $\mathrm{COD}_{\mathrm{Mn}}$ を測定した。紫外 線を照射することによって, 多くの試料において, $\mathrm{COD}_{\mathrm{Mn}}$ は低くなることを確認した。 しかしながら, 紫外線照射に より, $\mathrm{COD}_{\mathrm{Mn}}$ が高い有機化合物に変化する有機化合物や $254 \mathrm{~nm}$ に吸収帯がないために $\mathrm{COD}_{\mathrm{Mn}}$ が変化しなかった試 料もあり，あらゆる試料の $\mathrm{COD}_{\mathrm{Mn}}$ を低くさせることが可 能なわけではないということを確認した。最後に，紫外線 照射時間による $\mathrm{COD}_{\mathrm{Mn}}$ の変化を確認した。紫外線照射時 間が増大すると，分解率も上昇することを確認した． 50 $\mu \mathrm{M}$ グルコースにおいては, 7.85 分で分解し終えることが 確認できた．様々な二酸化チタンを試料と混合して光分解 装置を流してみたが, 現時点では遮光効果によって逆に分 解率は低下した。

結論として天然水の有機化合物 $\left(\mathrm{COD}_{\mathrm{Mn}}\right)$ を光分解する 方法として, 長光路の PFA マイクロチューブを使用する方 法は，一応実用化できると考えられる．また $\mathrm{COD}_{\mathrm{Mn}}$ を化 学発光により評価するシステムも有効であった. 試薬濃度 (緩衝液, ルミノール, 過マンガン酸イオン等) について, 最適化できたと考えられる，個々の試料について，問題点 (分解効率がバッチ法と異なる等) もあるが, 一応自動シス
テムとして稼働できると言える，またシステム自体，安価 かつ簡便であることも特質に挙げたい.

\section{文献}

1) S. Liu, Y. Wang, S. Yin, T. Sato: Research on Chemical Intermediates, 36, 39 (2010).

2) M. Kaneko, S. Suzuki, H. Ueno, J. Nemoto, Y. Fujii, Yuki : Electrochimica Acta, 55, 3068 (2010).

3) R. T. Zehr, N. A. Deskins, M. A. Henderson : Journal of Physical Chemistry C, ACS, ASAP DOI : 10.1021/ jp910507k Publication Date (Web) February 12, 2010.

4) R. L. Pozzo, R. J. Brandi, A. E. Cassano, M. A. Baltanas : Chemical Engineering Science, 65, 1345 (2010).

5) Y. Su, X. Li, H. Lv, X. Hou : Microchem. J., 87, 56 (2007).

6) G. Cao, Y. Li, Q. Zhang, H. Wang: J. Am. Chem. Soc., 93, 25 (2010).

7) B.-D. Lee, M. Hosomi : Environ. Chem. Lett., 8, 139 (2010).

8) J. De Laat, N. Boudiaf, F. Dossier-Berne : Water Res., 44, 3261 (2010).

9) Y. Wu, M. Xing, J. Zhang, F. Chen : Appl. Catalysis, B : Environmental, 97, 182 (2010).

10) R. Zhang, H. Wu, W. Pei : J. Am. Ceram. Soc., 93, 605 (2010)

11) L. Cai, X. Liao, B. Shi : Ind. Eng. Chem. Res., 49, 3194 (2010).

12) H. W. Choi, E. J. Kim, S. H. Hahn : Chem. Eng. J., 161, 285 (2010).

13) J.-Z. Kong, A.-P. Li, X.-Y. Li, H.-F. Zhai, W.-Q. Zhang, Y.-P. Gong, H. Li, D. Wu : J. Solid State Chem., 183, 1359 (2010).

14) W. Liu, Z. Zhang, Y. Zhang: Microchim. Acta, 160, 141 (2008).

15) H. Yao, B. Wu, H. Qu, Y. Cheng: Anal. Chim. Acta, 633, 76 (2009). 


\title{
Construction of Photo-Decomposer for Organic Compounds in Natural Water and Evaluation of Its Performance by Chemiluminescence
}

\author{
Kitao FujIwara ${ }^{1}$, Yuta Osako ${ }^{1}$, Takana SASAKI ${ }^{1}$, Hidetoshi Kumata ${ }^{1}$, \\ Motohide AOKI ${ }^{1}$ and Norio KaWASHIMA ${ }^{2}$ \\ ${ }^{1}$ School of Life Sciences, Tokyo University of Pharmacy and Life sciences, 1932-1, Horinouchi, Hachiouji-shi, \\ Tokyo 192-0392 \\ ${ }^{2}$ Japan Industrial Water Association, 1-1, Kaguragashi, Shinjuku-ku, Tokyo 162-0823
}

(Received 30 April 2010, Accepted 20 July 2010)

COD (chemical oxygen demand) is one of the most popular methods for evaluating organic pollutants. In the present paper, a chemiluminescence detection method for measuring the concentration of permanganate ion after reacting with organic compounds is described; the chemiluminescence occurs based on the direct reaction between permanganate and luminol. In order to use this system, a buffer solution, the concentrations of permanganate and luminol were inspected. Fifty $\mu \mathrm{M}$ of $\mathrm{MnO}_{4}{ }^{-}$was reacted with the sample, and then the chemiluminescence was detected with a mixture solution $(250 \mathrm{~mL}$ of $1.5 \mathrm{mM}$ luminol, $250 \mathrm{~mL}$ of $0.01 \mathrm{M}$ 1,10-phenanthroline, and $500 \mathrm{~mL}$ of $1 \mathrm{M}$ ammonium sulfate at $\mathrm{pH} 9.6$ (adjusted with $25 \%$ ammonium solution). Also, a method for reducing the COD was proposed : where the sample solution flows a $100 \mathrm{~m}$ length PFA (perfluoroalkoxy-fluororesin) microtube (i.d. $=0.2 \mathrm{~mm}$ and o.d. $=0.4 \mathrm{~mm})$. The PFA tube was wound around the outside of a quartz tube $($ o.d. $=30 \mathrm{~mm}$, length $=120 \mathrm{~mm})$. Two low-pressure mercury lamps $(5 \mu \mathrm{W}$ at $1 \mathrm{~m}$ distance $)$ were inserted into the quartz tube. It could be calculated that about $45 \%$ of $254 \mathrm{~nm}$ radiation of the lamp reached the inside the PFA microtube. When this photo-decomposition system is applied, 0 to $90 \%$ of COD can be reduced. A total flow system for the photo-decomposition-chemiluminescence detection system for COD was constructed.

Keywords : chemiluminescence ; chemical oxygen demand (COD); natural water ; flow system ; photo-decomposition ; low pressure mercury lamp. 